\title{
Differential expression of lipoprotein genes in Mycoplasma pneumoniae after contact with human lung epithelial cells, and under oxidative and acidic stress
}

\author{
Katri M Hallamaa*1, Sen-Lin Tang ${ }^{1,2}$, Nino Ficorilli ${ }^{1}$ and Glenn F Browning ${ }^{1}$
}

Address: ${ }^{1}$ Department of Veterinary Science, The University of Melbourne, Parkville, Victoria 3010, Australia and ${ }^{2}$ Microbial Biodiversity Laboratory, Research Center for Biodiversity, Academia Sinica, NanKang, Taipei, 11528, Taiwan

Email: Katri M Hallamaa* - k.hallamaa@pgrad.unimelb.edu.au; Sen-Lin Tang - sltang@gate.sinica.edu.tw; Nino Ficorilli - n.ficorilli@unimelb.edu.au; Glenn F Browning - glenfb@unimelb.edu.au

* Corresponding author

Published: 23 July 2008

BMC Microbiology 2008, 8:124 doi:10.1 186/147I-2180-8-124
Received: 26 February 2008

Accepted: 23 July 2008

This article is available from: http://www.biomedcentral.com//47/ -2/80/8//24

(C) 2008 Hallamaa et al; licensee BioMed Central Ltd.

This is an Open Access article distributed under the terms of the Creative Commons Attribution License (http://creativecommons.org/licenses/by/2.0), which permits unrestricted use, distribution, and reproduction in any medium, provided the original work is properly cited.

\begin{abstract}
Background: Mycoplasma pneumoniae is a human pathogen that is a common cause of communityacquired pneumonia. It harbours a large number of lipoprotein genes, most of which are of unknown function. Because of their location on the cell surface, these proteins are likely to be involved in the bacterial response to environmental changes, or in the initial stages of infection. The aim of this study was to determine if genes encoding surface lipoproteins are differentially expressed after contact with a human cell line, or after exposure to oxidative or acidic stress.
\end{abstract}

Results: Using qRT-PCR assays, we observed that the expression of a number of lipoprotein genes was up-regulated when $M$. pneumoniae was placed in contact with human cells. In contrast, lipoprotein expression was generally down-regulated or unchanged when exposed to either hydrogen peroxide or low $\mathrm{pH}$ (5.5). When exposed to low $\mathrm{pH}$, the mRNA levels of four polycistronically transcribed genes in Lipoprotein Multigene Family 6 formed a gradient of decreasing quantity with increasing distance from a predicted promoter.

Conclusion: The demonstrated transcriptional changes provide evidence for the functionality of these mostly unassigned genes and indicate that they are regulated in response to changes in environmental conditions. In addition we have shown that the members of Lipoprotein Gene Family 6 may be expressed polycistronically.

\section{Background}

Mycoplasma pneumoniae is one of the most common causes of community acquired pneumonia [1]. It is thought to be an extracellular pathogen that colonizes the surface of epithelial cells, although there are reports suggesting that it is capable of invading host cells [2,3]. Mycoplasmas lack a cell wall, and, hence, their membranebound proteins are exposed to the external environment and to their host's immune response. In spite of their apparent vulnerability to immune responses, they establish chronic infections.

The M. pneumoniae genome has a high proportion of genes predicted to encode lipoproteins $(6.68 \%$ of all genes) and 67 of these are members of six lipoprotein gene families $[4,5]$. A full description of these gene fami- 
lies, including their genomic locations, has been published previously [5]. The functionality of these genes is unknown, but because their products are cell surface proteins they could potentially play a role in adhesion and/or the initial stages of infection. The members of Lipoprotein Gene Family 2 are homologs of an M. hyopneumoniae lipoprotein located immediately upstream of a conserved $A B C$ transport operon containing an exonuclease [6]. Little is known about general stress responses in M. pneumoniae, with only one study exploring the effects of heat shock [7], and another reporting changes in the global protein synthesis pattern in response to the presence of glycerol [8]. It has been suggested that the genome lacks many of the transcriptional regulators found in other bacteria. For example, no two-component regulatory system and only one sigma factor has been identified [4,9]. Hence, the extent of transcriptional regulation and the mechanisms involved remain largely unknown in this organism.

Understanding the changes in lipoprotein gene expression in response to different environmental conditions is an important first step in elucidating the possible functions of these genes and their transcriptional regulation in M. pneumoniae. Genes that are regulated after contact with host cells or under oxidative stress may play an important role in pathogenesis. In this study we used quantitative reverse transcriptase polymerase chain reaction assays (qRT-PCR) and a cell culture model employing the human lung carcinoma epithelial cell line A549 to examine changes in lipoprotein gene expression in M. pneumoniae in response to association with host cells. The A549 cell line has been used in previous studies of adhesion, infection or internalization by M. pneumoniae [3,10-12]. We also investigated changes in lipoprotein gene expression after oxidative stress or exposure to low $\mathrm{pH}$, mimicking host defence mechanisms the bacteria may encounter upon infection. In total, 28 genes were chosen as representative of all lipoprotein genes and their response to changes in environmental conditions was investigated (Table 1). These 28 genes were selected to include at least one full-length ORF from each phylogenic group within the lipoprotein gene families [5].

\section{Methods}

\section{Bacterial strain and culture conditions}

M. pneumoniae strain M129 was cultured in $150 \mathrm{~cm}^{2}$ tissue culture flasks (Falcon, Becton Dickinson) in Modified Hayflick Medium [15] supplemented with $20 \%$ horse serum (Sigma $\mathrm{H}-1138$ ) at $37^{\circ} \mathrm{C}$ until a colour change was seen in the medium (1-2 days).

\section{The human cell line and culture conditions}

The human lung cell line A549 was initially grown in flasks at $37^{\circ} \mathrm{C}$ in Minimum Essential Medium (MEM) supplemented with $5 \%$ fetal calf serum (FCS), $5 \mathrm{mM}$ sodium hydrogen carbonate, $10 \mathrm{mM}$ HEPES ( $\mathrm{pH} 7.4$ ) and ampicillin $(50 \mu \mathrm{g} / \mathrm{ml})$. The cells were subsequently cultured in 6-well tissue culture plates at $37^{\circ} \mathrm{C}$ in Dulbecco's Modified Eagle's Medium (DMEM) supplemented with $5 \%$ FCS, $44 \mathrm{mM}$ sodium hydrogen carbonate and ampicillin $(50 \mu \mathrm{g} / \mathrm{ml})$ in $5 \% \mathrm{CO}_{2} /$ air, or in Leibovitz's $\mathrm{L} 15$ medium supplemented with 5\% FCS, 10 mM HEPES (pH $7.4)$ and ampicillin $(50 \mu \mathrm{g} / \mathrm{ml})$ in air.

\section{Infection model}

M. pneumoniae M129 cultured in a $150 \mathrm{~cm}^{2}$ cell culture flask were scraped from the plastic into MEM supplemented with $100 \mathrm{U}$ penicillin/ml. The suspension was passed through a 27-gauge needle to separate the cells.

Two millilitres of fresh MEM containing 5\% FCS was added to the wells containing confluent cultures of A549 cells and $250 \mu \mathrm{l}$ of the mycoplasma suspension was added to each well (an approximate multiplicity of infection of 100). As a control, the mycoplasma suspension was added to a well containing MEM supplemented with $5 \%$ FCS but not cells. The plates were incubated at $37^{\circ} \mathrm{C}$ for $15 \mathrm{~min}$, $30 \mathrm{~min}, 1 \mathrm{~h}$ or $2 \mathrm{~h}$. All time points were chosen to be less than the doubling time for $M$. pneumoniae to ensure that replication did not affect interpretation of the assay. Following incubation the medium was removed and the wells were washed twice with $2 \mathrm{ml}$ of $\mathrm{PBS}$ at $37^{\circ} \mathrm{C}$ to remove non-adherent mycoplasmas. A $600 \mu$ l volume of RLT buffer (RNeasy kit, Qiagen) was added to each well and the cells were collected using a cell scraper. The cell lysate was passed through a 20-gauge needle at least 5 times and RNA was isolated using a Qiagen RNeasy kit as per the manufacturer's instructions. RNA was eluted in 50 $\mu \mathrm{l}$ of DEPC-treated water and stored at $-70^{\circ} \mathrm{C}$. Three independent experiments were carried out, each containing three biological replicates.

\section{$\mathrm{H}_{2} \mathrm{O}_{2}$ stress test}

M. pneumoniae M129 was cultured in $25 \mathrm{~cm}^{2}$ cell culture flasks. The cells were then incubated for $10 \mathrm{~min}$ in Modified Hayflick Medium at $37^{\circ} \mathrm{C}$ supplemented with $1 \mathrm{mM}$ or $20 \mathrm{mM} \mathrm{H}_{2} \mathrm{O}_{2}$. No $\mathrm{H}_{2} \mathrm{O}_{2}$ was added to the negative control. The medium was discarded and RNA was isolated as described above. This experiment was repeated four times.

\section{Low pH stress test}

M. pneumoniae M129 was cultured in $25 \mathrm{~cm}^{2}$ cell culture flasks. The cells were then incubated for $10 \mathrm{~min}$ in Modified Hayflick Medium, with the $\mathrm{pH}$ adjusted to 5.5 or 7.4 (control) at $37^{\circ} \mathrm{C}$. The medium was discarded and RNA was isolated as described above. This experiment was repeated three times. 
Table I: Oligonucleotides used for qPCR

\begin{tabular}{|c|c|c|c|}
\hline Family & Gene annotation (NCBI) & Forward primer & Reverse primer \\
\hline$H_{K G}{ }^{a}$ & MPN430 & GACGTATTGGACGCCTTGTT & GTCGTTAACGGCAACGATCT \\
\hline HKG & MPN665 & GGCAAGAACACCCCTATT & TAGGATCACCTTCAAGCG \\
\hline HKG & MPN003 & GGGGAAGTGATTGGTGAT & TTGGTACCGTGTTCCTTG \\
\hline \multirow[t]{6}{*}{1} & MPN084 & AACCCATTTCTTTGCATTGG & GTTTTGGGGATTGCTGATGT \\
\hline & MPN59I & ACACAACTGTGGGAATGCAA & CCCTGCCTTAGGTTTTTTGGT \\
\hline & MPN592 & TGCTTGCTCTGCTACGCTAA & GCTCAATGGTGGTTGAGGTT \\
\hline & MPN083 & ACCAACGGTTTTTGAACAGC & GCATCATTGGGGTTGGATAG \\
\hline & MPN588 & AAAGCCTTGGTTTCGATTCA & TGCCAGGAAGACTTGTTGTG \\
\hline & MPN582 & TGTGCGAACCGTTGATTTTA & CTAATTTGCTTGGTGCGACA \\
\hline \multirow[t]{4}{*}{2} & MPNI99 & AGTTTCCGCTAGTTCGTTGC & GTTTTTGCGGCATCTTCAAT \\
\hline & MPN408 & АТTСССАТTТСССТTТССАС & CATTTGAGCACCGTTTTCCT \\
\hline & MPN200 & TTCCGGTCTCTGTTTCGACT & TCTTTTTGTGCGCCCTTACT \\
\hline & MPNI52 & CGATTAATGGACCCGTTTTG & TCTTTGCACCGAAGTGACAG \\
\hline \multirow[t]{3}{*}{3} & MPN436 & CCCAGTCAAGGGTTAGGTCA & TCTTCGGCAAAGAAAGGAAA \\
\hline & MPN444 & AACCGAAGTCAAAAACCC & GAAGTGTCATCAGCAGCC \\
\hline & MPN489 & GATGGTAGTTACCCCGCT & ACTAAAGCGGCAGATCCT \\
\hline 4 & MPN456 & AGCTGCACAAAGAAGCAC & CTTGAGTGCCGTTACCAC \\
\hline \multirow[t]{5}{*}{5} & MPNOII & AAAGGCATTAGCGATGTTTCA & AATGTTTGTCACCTTTGTGGA \\
\hline & MPNOI2 & AGAGTGCGGAAAAAGGTGAA & AAAGGATCATTGCCTGTTGC \\
\hline & MPN4II & GGTATTGCGGAACTTGCTTT & TCAACTTTCCGCTCCATTTT \\
\hline & MPN27I & TGCGGATTTTGATTTTGACC & GATCAACCTTTCGCTCCATC \\
\hline & MPN505 & TTTGAAAAGGGCGAATTAGG & TGATCAACCTTTCGCTCAAA \\
\hline \multirow[t]{9}{*}{6} & MPN647 & ATGGATCCTTCCCGTTTTTC & CCGGGATAAGTTTCTGCAAG \\
\hline & MPN646 & TGAACTGGGCGATAAGGAAG & AACAAATTTGAAGCAGGTGGA \\
\hline & MPN645 & TGGCGGAGTAAAAGAAACTGA & TCAAAAGAAGTGGCACCAAA \\
\hline & MPN644 & GGAGTGCAAAGCCAAAAAGT & CTTCACCACTGCCAACAATG \\
\hline & MPN643 & TGGCAGAAGCATTGAAGATG & TGTGTGTATCTTTCCACCAAGC \\
\hline & MPN642 & CCACATAAAGATGGAAGGGATG & TCCAGTATATTCACTTTCTTCTACGC \\
\hline & MPN64I & TCAATTGAGGGAAGGCGTTA & TGCAGTGACTCCACAAAAGC \\
\hline & MPN640 & TTCGGGAGGTAAAGGTAGCA & TGAATTTGGCTTTTTCACCA \\
\hline & MPN639 & CGCGAAAGTTACGGCTTAAA & AAGCGGCCTACTTCAGTTTG \\
\hline
\end{tabular}

a housekeeping gene

\section{DNase treatment of RNA}

RNA was treated with DNase prior to RT-PCR. A $15 \mu \mathrm{l}$ aliquot of RNA was treated with $2 \mathrm{U}$ of RNase-free DNase I (Novagen) in a final volume of $25 \mu \mathrm{l}$ at $37^{\circ} \mathrm{C}$ for $30 \mathrm{~min}$ utes. The reaction was stopped by the addition of $50 \mathrm{mM}$ EDTA to a final concentration of $4.5 \mathrm{mM}$, followed by incubation at $70^{\circ} \mathrm{C}$ for 5 minutes.

\section{Reverse transcription}

Reverse transcription was carried out by incubating $0.5 \mu \mathrm{l}$ random primers ( $3 \mu \mathrm{g} / \mu \mathrm{l}$, Invitrogen), $1 \mu \mathrm{l} \mathrm{dNTPs} \mathrm{(10} \mathrm{nM}$ each) and $10 \mu \mathrm{l}$ DNase-treated RNA at $65^{\circ} \mathrm{C}$ for $10 \mathrm{~min}$ utes, and then adding $2.5 \mu \mathrm{l} 10 \times$ reaction buffer (F-570B, Finnzymes), $0.5 \mu \mathrm{l}$ RNase inhibitor (RNAguard, Amersham Biosciences), $0.5 \mu \mathrm{l}$ AMV-RT (F-570S, Finnzymes) and DEPC-treated water to a final volume of $25 \mu \mathrm{l}$. The reaction was incubated for 10 minutes at $25^{\circ} \mathrm{C}, 30 \mathrm{~min}$ at $42^{\circ} \mathrm{C}$, and then 2 min at $94^{\circ} \mathrm{C}$. The cDNA was diluted 1:10 with distilled water and used as template for qPCR. As a control for detecting possible DNA contamination in samples, a duplicate reverse transcription reaction for each sample was performed without the addition of AMVRT. The control reactions were treated identically to samples in the subsequent dilution step and in qPCR.

\section{Quantitative PCR}

The qPCR reactions were carried out using a Stratagene MX3000P ${ }^{\circledast}$ System and Platinum SYBR Green qPCR SuperMix-UDG (Invitrogen) chemistry. Expression ratios were calculated using REST 2005 [16]. Reactions consisted of $1 \times$ Platinum SYBR Green qPCR SuperMix-UDG containing the ROX reference dye at a final concentration of $50 \mathrm{nM}, 0.75 \mu \mathrm{M}$ forward primer, $0.75 \mu \mathrm{M}$ reverse primer, $5 \mu \mathrm{l}$ of template and distilled water to a final volume of 20 
$\mu \mathrm{l}$. The reactions were incubated at $50^{\circ} \mathrm{C}$ for $2 \mathrm{~min}$, then $95^{\circ} \mathrm{C}$ for $5 \mathrm{~min}$, then 40 cycles of $95^{\circ} \mathrm{C}$ for $30 \mathrm{~s}$ and $60^{\circ} \mathrm{C}$ for $30 \mathrm{~s}$. Melting curve analysis was performed at the end of the amplification.

The qPCR efficiency for each primer pair was determined by running a tenfold dilution series in triplicate using M129 genomic DNA as template, at concentrations ranging from $0.5 \mathrm{pg}$ to $5 \mathrm{ng}$ per reaction, covering a cycle threshold (CT) range from approximately 15 to 30 . The specificity of each primer pair was confirmed by melting curve analysis and subsequent agarose gel electrophoresis of qPCR products. All primer pairs produced a PCR product with a single peak in melting curve analyses and a single band after gel electrophoresis. Oligonucleotide primer sequences used in this study are provided in Table 1.

Three housekeeping genes, for glyceraldehyde-3-phosphate dehydrogenase (gap, also known as MPN430), elongation factor Tu (tuf, also known as MPN665) and DNA gyrase subunit B (gyrB, also known as MPN003), were validated in an adhesion assay by ensuring that the relative expression of each gene remained constant before and after contact of M. pneumoniae M129 cells with A549 cells. Two housekeeping genes were used for normalisation when analysing $\mathrm{H}_{2} \mathrm{O}_{2}$-treated samples, glyceraldehyde-3-phosphate dehydrogenase (gap or MPN430) and elongation factor Tu ( $t u f$ or MPN665). The expression of gyrB was not stable after exposure to $\mathrm{H}_{2} \mathrm{O}_{2}$. The expression of all three housekeeping genes was stable after exposure to low $\mathrm{pH}$, so all three genes were used for normalisation of low pH stress samples.

\section{Statistical analysis}

Statistical analysis of qPCR data was carried out using the randomisation test included in REST 2005 [16]. A P value of less than 0.05 was considered significant.

\section{Results}

Several lipoprotein genes were up-regulated after mycoplasma contact with human A549 cells

In total, six different genes in four distinct lipoprotein gene families were significantly up-regulated in M. pneumoniae after binding to A549 cells for 2 hours: MPN588 in lipoprotein Family 1; MPN199 and MPN200 in Family 2; MPN456 in Family 4; and MPN011 and MPN411 in Family 5 (Table 2). Of these genes, only MPN456 has sequence similarity to a gene of known function. BlastX analysis detected $61 \%$ identity with a homolog of a predicted component of a predicted oligopeptide ABC transport system (COG4166) in M. genitalium G-37 [5]. All of these genes appeared to be up-regulated after $15 \mathrm{~min}, 30$ min and $1 \mathrm{~h}$ of incubation (see Additional file 1: Change in lipoprotein gene expression in M. pneumoniae after binding to A549 cells), although these results were not statistically significant.

\section{Two lipoprotein genes were down-regulated in response to hydrogen peroxide}

Two lipoprotein genes, MPN489 in Family 3 and MPN639 in Family 6, were down-regulated when mycoplasma cells were incubated in growth medium supplemented with $20 \mathrm{mM} \mathrm{H}_{2} \mathrm{O}_{2}$ (Table 2). In addition, several genes in Family 2, MPN408, MPN200 and MPN152, MPN436 in Family 3, MPN012 and MPN505 in Family 5, and MPN646, MPN647 and MPN641 in Family 6 appeared to be down-regulated, although the results were not statistically significant. The lower concentration of $\mathrm{H}_{2} \mathrm{O}_{2}(1 \mathrm{mM})$ had no significant effect on lipoprotein gene expression (see Additional file 2: Change in lipoprotein gene expression in M. pneumoniae after exposure to 1 $\mathrm{mM} \mathrm{H}_{2} \mathrm{O}_{2}$ for 10 minutes).

\section{Three lipoprotein genes were down-regulated after acid stress}

Three genes in Family 2, MPN408, MPN200 and MPN152, were significantly down-regulated after the cells were exposed to $\mathrm{pH} 5.5$ for ten minutes (Table 2). Interestingly, after low pH stress, the relative mRNA concentrations of four consecutive genes in Family 6, MPN647, MPN646, MPN645 and MPN644, formed a decreasing gradient $\left(\mathrm{R}^{2}=0.997\right)$. By employing oligonucleotides bridging adjacent ORFs in RT-PCR, these genes were shown to be polycistronically expressed (see Additional file 3: Four consecutive genes in Family 6, MPN647, MPN646, MPN645 and MPN644 are polycistronically expressed as shown by RT-PCR).

\section{Family 2 had the most diverse expression profiles under different environmental conditions}

MPN200 in Family 2 was the only gene affected by more than one of the environmental conditions tested. This gene was up-regulated after contact with A549 cells and down-regulated after exposure to low $\mathrm{pH}$.

\section{Discussion}

In this study we report transcriptional changes in the expression of $M$. pneumoniae lipoprotein genes in response to contact with human epithelial cells in vitro, and provide further evidence of transcriptional regulation in mycoplasmas in response to environmental conditions [7,17-19]. We chose qRT-PCR as the method to study changes in gene expression. Although microarray and qRT-PCR results generally correlate well, both oligonucleotide and cDNA arrays have a tendency to underestimate the fold-change ratios of the underlying mRNAs compared to qRT-PCR [14]. Thus, qRT-PCR is more sensitive in detecting smaller changes in gene expression [13]. 
Table 2: Changes in M. pneumoniae lipoprotein gene expression after contact with human A549 cells for 2 hours, or after incubation in $20 \mathrm{mM} \mathrm{H}_{2} \mathrm{O}_{2}$ or at $\mathrm{pH} 5.5$ for $10 \mathrm{~min}$

\begin{tabular}{|c|c|c|c|c|c|c|c|}
\hline \multirow[t]{2}{*}{ Lipoprotein family } & \multirow{2}{*}{$\begin{array}{l}\text { Gene annotation } \\
\text { (NCBI) }\end{array}$} & \multicolumn{6}{|c|}{ Change in expression (fold) after: } \\
\hline & & $\begin{array}{l}\text { Contact with A549 } \\
\text { cells\# }\end{array}$ & $P$ value & $\begin{array}{l}20 \mathrm{mM} \mathrm{H}_{2} \mathrm{O}_{2} \text { for } 10 \\
\min \dagger\end{array}$ & $P$ value & $\mathrm{pH} 5.5$ for $10 \mathrm{~min} \S$ & $P$ value \\
\hline \multirow[t]{6}{*}{1} & MPN084 & 1.1 & 0.714 & 0.5 & 0.439 & 1 & 0.910 \\
\hline & MPN59I & I & 0.966 & 0.8 & 0.645 & 1.6 & 0.275 \\
\hline & MPN592 & 0.9 & 0.880 & 0.9 & 0.906 & 0.9 & 0.825 \\
\hline & MPN083 & 1 & 0.934 & 1.7 & 0.504 & 1.3 & 0.605 \\
\hline & MPN588 & 1.9 & $0.002 * *$ & 0.6 & 0.475 & 0.8 & 0.504 \\
\hline & MPN582 & 1.2 & 0.586 & 0.4 & 0.375 & 0.6 & 0.222 \\
\hline \multirow[t]{4}{*}{2} & MPNI99 & 2.5 & $0.003 * *$ & 0.6 & 0.443 & 0.6 & 0.220 \\
\hline & MPN408 & 0.8 & 0.469 & 0.4 & 0.105 & 0.2 & $0.00 I^{* * *}$ \\
\hline & MPN200 & 3.3 & $0.006 * *$ & 0.4 & 0.195 & 0.4 & $0.037 *$ \\
\hline & MPNI52 & 1.2 & 0.677 & 0.2 & 0.104 & 0.2 & $0.020 *$ \\
\hline \multirow[t]{3}{*}{3} & MPN436 & 0.9 & 0.802 & 0.4 & 0.094 & 0.9 & 0.836 \\
\hline & MPN444 & 1.3 & 0.549 & 0.7 & 0.240 & 0.8 & 0.555 \\
\hline & MPN489 & 1.4 & 0.286 & 0.6 & $0.033^{*}$ & 0.7 & 0.328 \\
\hline 4 & MPN456 & 2.2 & $0.010 *$ & 0.8 & 0.681 & 0.5 & 0.082 \\
\hline \multirow[t]{5}{*}{5} & MPNOII & 1.6 & $0.044 *$ & 0.4 & 0.299 & 0.6 & 0.316 \\
\hline & MPNOI2 & 1.5 & 0.119 & 0.3 & 0.122 & 0.6 & 0.257 \\
\hline & MPN4I I & 1.9 & $0.032 *$ & 0.5 & 0.345 & 0.7 & 0.442 \\
\hline & MPN27I & 1.2 & 0.638 & 0.6 & $0.45 I$ & 0.9 & 0.794 \\
\hline & MPN505 & 0.8 & 0.602 & 0.3 & 0.095 & 1.5 & 0.302 \\
\hline \multirow[t]{9}{*}{6} & MPN647 & 1.2 & 0.603 & 0.4 & 0.130 & 2.3 & 0.081 \\
\hline & MPN646 & 0.9 & 0.846 & 0.5 & 0.097 & 1.8 & 0.177 \\
\hline & MPN645 & 1.4 & 0.360 & 0.5 & 0.624 & 1.3 & 0.398 \\
\hline & MPN644 & I.I & 0.876 & 0.6 & 0.358 & 0.9 & 0.753 \\
\hline & MPN643 & 1.5 & 0.208 & 0.6 & 0.503 & 1.1 & 0.831 \\
\hline & MPN642 & I.I & 0.895 & 0.6 & 0.323 & 0.7 & 0.457 \\
\hline & MPN64I & 1.7 & 0.208 & 0.5 & 0.063 & 0.6 & 0.264 \\
\hline & MPN640 & I & 0.980 & 0.6 & 0.431 & 0.9 & 0.658 \\
\hline & MPN639 & 1.1 & 0.766 & 0.3 & $0.007 * *$ & 0.8 & 0.514 \\
\hline
\end{tabular}

\footnotetext{
$* P$ value $<0.05$

** $P$ value $<0.01$.

\# Mean of three independent experiments, each containing three biological replicates.

$\dagger$ Mean of four independent experiments.

$\S$ Mean of three independent experiments.
}

The hydrogen peroxide concentrations used in this study were chosen to have a minimal impact on cell viability, based on unpublished studies by Zimmermann and Herrmann [20]. A pH of 5.5 was used in the acidic stress test and was chosen to be below the $\mathrm{pH}$ of exhaled breath concentrate ( $\mathrm{pH}$ 6.4) [21] but above the $\mathrm{pH}$ of 4.8 found in lysosomes. In this study mycoplasma cells were exposed to low $\mathrm{pH}$ or hydrogen peroxide for 10 minutes before changes in gene expression were measured. Similar hydrogen peroxide treatment times have been used previously in gene expression studies of $M$. pneumoniae $[7,20]$ and Haemophilus influenzae [22]. In our cell culture infection model we allowed the mycoplasma cells to be in contact with eukaryotic cells for 15, 30, 60 and 120 minutes. This timeframe was chosen to investigate changes in gene expression during the initial stages of infection, but prior to any replication.

Global transcriptional changes in M. pneumoniae after heat shock have been studied using microarray technology [7]. Forty-seven genes were up-regulated after heat shock at $43^{\circ} \mathrm{C}$, while 30 genes were down-regulated in the same conditions. Of the genes analysed in our study, only three genes showed differential expression in response to heat shock; MPN199 and MPN200 in Family 2 were upregulated, whereas MPN591 in Family 1 was down-regu- 
lated. This is in agreement with our observation that Family 2 genes appear to be regulated in response to a variety of environmental conditions. Recently, in a microarray study of transcriptional regulation in M. gallisepticum associated with eukaryotic cells, 58 genes were found to be either up- or down-regulated [17]. The expression of $M$. gallisepticum genes homologous to M. pneumoniae lipoproteins in multigene Families 1, 2, 3, and 4 was not affected by contact with eukaryotic cells as detected by microarray.

All genes, apart from MPN456, that were differentially expressed in this study are hypothetical genes with no assigned function. The results from this study imply that these genes could be functional and that their gene products may play a role in adaptation to different environmental conditions. Two genes that belong to a gene family unique to M. pneumoniae, MPN011 and MPN411, were up-regulated when the cells were in contact with A549 cells, suggesting that the genes in this family could be involved in adhesion or in the initial stages of infection. MPN456, a homolog of a predicted component of a predicted oligopeptide ABC transport system (COG4166), was also up-regulated after adhesion to A549 cells. This could indicate regulation in response to a requirement for transport of substrates from the host cell or involvement in adhesion, as in M. hominis, in which a substrate-binding domain of a peptide transport system (OppA) mediates cytadherence $[23,24]$. However, further studies are needed to understand the role of these genes in vivo and whether the changes observed in gene expression of $M$. pneumoniae during association with human cells are due to adhesion, invasion or other interactions with the cell, although some recent reports of the ability of $M$. pneumoniae to invade human cells have been contradictory $[2,3,25]$.

After acidic stress the mRNA of four genes in Family 6 formed a decreasing concentration gradient, in correlation with their distance from a predicted promoter [26]. By employing RT-PCR and oligonucleotides bridging the adjacent coding sequences, these genes were shown to be expressed polycistronically, contrary to our previous findings [5]. A positive correlation between mRNA levels and proximity to a promoter was also observed by Benders et al. [27] when they measured mRNA levels of the fts $Z$ gene cluster in M. pneumoniae. Groups of functionally related genes in $M$. pneumoniae and $M$. genitalium are often preceded by promoters. However no transcriptional terminators are located downstream of these genes to prevent follow-through of transcription to subsequent ORFs [27]. It has been proposed that there are only a few transcriptional terminators in the mycoplasma genomes $[28,29]$ and, therefore, that the transcription of many genes may be initiated from upstream promoters located in front of other genes, not all of which are necessarily functionally related to those downstream.

\section{Conclusion}

In summary, we have assessed transcriptional responses of $M$. pneumoniae after association with host cells and after exposure to hydrogen peroxide or low pH. A $20 \mathrm{mM}$ concentration of $\mathrm{H}_{2} \mathrm{O}_{2}$ induced a trend towards general down-regulation of lipoprotein genes, whereas low $\mathrm{pH}$ had a more diverse effect on lipoprotein gene expression. Adhesion of mycoplasma cells to A549 cells resulted in up-regulation of selected genes, but the expression of most genes remained unaffected. These observations of transcriptional changes provide evidence for the functionality of these mostly unassigned genes and indicate that they may have a role in responses by $M$. pneumoniae to environmental changes.

\section{Authors' contributions}

KMH carried out the molecular genetic studies, analysed the data and drafted the manuscript. NF cultured the eukaryotic cells. S-LT and GFB participated in the design and co-ordination of the study and helped to draft the manuscript. All authors read and approved the final manuscript.

\section{Additional material}

\section{Additional file 1}

Change in lipoprotein gene expression in M. pneumoniae after binding to A549 cells. Expression ratios after $15 \mathrm{~min}, 30 \mathrm{~min}$ and $1 \mathrm{~h}$.

Click here for file

[http://www.biomedcentral.com/content/supplementary/1471-

2180-8-124-S1.pdf]

\section{Additional file 2}

Change in lipoprotein gene expression in $\mathrm{M}$. pneumoniae after exposure to $1 \mathrm{mM} \mathrm{H}_{2} \mathrm{O}_{2}$ for 10 minutes.

Click here for file

[http://www.biomedcentral.com/content/supplementary/1471-

2180-8-124-S2.pdf]

\section{Additional file 3}

Four consecutive genes in Family 6, MPN647, MPN646, MPN645 and MPN644 are polycistronically expressed as shown by RT-PCR.

Click here for file

[http://www.biomedcentral.com/content/supplementary/1471-

2180-8-124-S3.pdf]

\section{Acknowledgements}

This work was supported by an NHMRC project grant.

\section{References}

I. Foy HM: Infections caused by Mycoplasma pneumoniae and possible carrier state in different populations of patients. Clin Infect Dis 1993, 17 Suppl I:S37-46. 
2. Meseguer MA, Alvarez A, Rejas MT, Sanchez C, Perez-Diaz JC, Baquero F: Mycoplasma pneumoniae: a reduced-genome intracellular bacterial pathogen. Infect Genet Evol 2003, 3:47-55.

3. Yavlovich A, Tarshis M, Rottem S: Internalization and intracellular survival of Mycoplasma pneumoniae by non-phagocytic cells. FEMS Microbiol Lett 2004, 233:24I-246.

4. Dandekar T, Huynen M, Regula JT, Ueberle B, Zimmermann CU, Andrade MA, Doerks T, Sánchez-Pulido L, Snel B, Suyama M, Yuan YP, Herrmann R, Bork P: Re-annotating the Mycoplasma pneumoniae genome sequence: adding value, function and reading frames. Nucleic Acids Res 2000, 28:3278-3288.

5. Hallamaa KM, Browning GF, Tang SL: Lipoprotein multigene families in Mycoplasma pneumoniae. J Bacteriol 2006, 188:5393-5399.

6. Schmidt JA, Browning GF, Markham PF: Mycoplasma hyopneumoniae $\mathrm{mhp} 379$ is a $\mathrm{Ca}^{2+}$-dependent, sugar-nonspecific exonuclease exposed on the cell surface. J Bacteriol 2007, | 89:34|4-3424.

7. Weiner J 3rd, Zimmerman CU, Göhlmann HW, Herrmann R: Transcription profiles of the bacterium Mycoplasma pneumoniae grown at different temperatures. Nucleic Acids Res 2003 31:6306-6320

8. Halbedel S, Eilers H, Jonas B, Busse J, Hecker M, Engelmann S, Stülke $\mathrm{J}$ : Transcription in Mycoplasma pneumoniae: analysis of the promoters of the ackA and Idh Genes. J Mol Biol 2007, 371:596-607.

9. Himmelreich R, Hilbert $\mathrm{H}$, Plagens $\mathrm{H}$, Pirkl E, Li BC, Herrmann R: Complete sequence analysis of the genome of the bacterium Mycoplasma pneumoniae. Nucleic Acids Res 1996, 24:4420-4449.

10. Hayakawa M, Taguchi H, Kamiya S, Fujioka Y, Watanabe H, Kawai S, Kobayashi H: Animal model of Mycoplasma pneumoniae infection using germfree mice. Clin Diagn Lab Immunol 2002, 9:669-676

II. Svenstrup HF, Nielsen PK, Drasbek M, Birkelund S, Christiansen G: Adhesion and inhibition assay of Mycoplasma genitalium and M. pneumoniae by immunofluorescence microscopy. J Med Microbiol 2002, $51: 361-373$.

12. Yang J, Hooper WC, Phillips DJ, Talkington DF: Regulation of proinflammatory cytokines in human lung epithelial cells infected with Mycoplasma pneumoniae. Infect Immun 2002, 70:3649-3655.

13. Dallas PB, Gottardo NG, Firth MJ, Beesley AH, Hoffmann K, Terry PA, Freitas JR, Boag JM, Cummings AJ, Kees UR: Gene expression levels assessed by oligonucleotide microarray analysis and quantitative real-time RT-PCR - how well do they correlate? BMC Genomics 2005, 6:59.

14. Yuen T, Wurmbach E, Pfeffer RL, Ebersole BJ, Sealfon SC: Accuracy and calibration of commercial oligonucleotide and custom cDNA microarrays. Nucleic Acids Res 2002, 30:e48.

15. Freundt EA: A collaborative assay of mycoplasma reference antisera. J Biol Stand I 983, I I :227-240.

16. Pfaffl MW, Horgan GW, Dempfle L: Relative expression software tool (REST) for group-wise comparison and statistical analysis of relative expression results in real-time PCR. Nucleic Acids Res 2002, 30:e36.

17. Cecchini KR, Gorton TS, Geary SJ: Transcriptional responses of Mycoplasma gallisepticum strain $\mathbf{R}$ in association with eukaryotic cells. J Bacteriol 2007, 189:5803-5807.

18. Madsen ML, Nettleton D, Thacker EL, Edwards R, Minion FC: Transcriptional profiling of Mycoplasma hyopneumoniae during heat shock using microarrays. Infect Immun 2006, 74:160-166.

19. Madsen ML, Nettleton D, Thacker EL, Minion FC: Transcriptional profiling of Mycoplasma hyopneumoniae during iron depletion using microarrays. Microbiology 2006, I 52:937-944.

20. Zimmerman C-UR, Herrmann R: Transcriptome analysis of Mycoplasma pneumoniae Subtypes MI29 and FH During Hydrogen Peroxide Induced Oxidative Stress. In International Organisation for Mycoplasmology I6th International Congress Edited by: Ayling RD, Citti C, Nicholas RAJ. Cambridge, UK; 2006:99.

21. Czebe K, Kullmann T, Csiszer E, Barat E, Horvath I, Antus B: Variability of exhaled breath condensate $\mathrm{pH}$ in lung transplant recipients. Respiration 2007, 75(3):322-7.

22. Harrison A, Ray WC, Baker BD, Armbruster DW, Bakaletz LO, Munson RS Jr: The OxyR regulon in nontypeable Haemophilus influenzae. J Bacteriol 2007, 189:1004-1012.

23. Henrich B, Hopfe M, Kitzerow A, Hadding U: The adherence-associated lipoprotein PI00, encoded by an opp operon struc- ture, functions as the oligopeptide-binding domain OppA of a putative oligopeptide transport system in Mycoplasma hominis. J Bacteriol 1999, I 8 I:4873-4878.

24. Hopfe M, Henrich B: OppA, the substrate-binding subunit of the oligopeptide permease, is the major Ecto-ATPase of Mycoplasma hominis. J Bacteriol 2004, 186:1021-1928.

25. Krunkosky TM, Jordan JL, Chambers E, Krause DC: Mycoplasma pneumoniae host-pathogen studies in an air-liquid culture of differentiated human airway epithelial cells. Microb Pathog 2007, 42:98-103.

26. Weiner J 3rd, Herrmann R, Browning GF: Transcription in Mycoplasma pneumoniae. Nucleic Acids Res 2000, 28:4488-4496.

27. Benders GA, Powell BC, Hutchison CA 3rd: Transcriptional analysis of the conserved fts $Z$ gene cluster in Mycoplasma genitalium and Mycoplasma pneumoniae. I Bacteriol 2005, 187:4542-455I.

28. Ermolaeva MD, Khalak HG, White O, Smith HO, Salzberg SL: Prediction of transcription terminators in bacterial genomes. Mol Biol 2000, 30 I:27-33.

29. Washio T, Sasayama J, Tomita M: Analysis of complete genomes suggests that many prokaryotes do not rely on hairpin formation in transcription termination. Nucleic Acids Res 1998, 26:5456-5463.
Publish with Biomed Central and every scientist can read your work free of charge

"BioMed Central will be the most significant development for disseminating the results of biomedical research in our lifetime. "

Sir Paul Nurse, Cancer Research UK

Your research papers will be:

- available free of charge to the entire biomedical community

- peer reviewed and published immediately upon acceptance

- cited in PubMed and archived on PubMed Central

- yours - you keep the copyright
BioMedcentral 